\title{
Fabricating Invention: The Patent Malfunction of Australian Patent Law
}

\author{
Hazel V. J. Moir ${ }^{1}$
}

\section{Abstract}

Despite advice to parliament that patents are granted only for 'a significant advance over what was known and what was available to the public ${ }^{2}$ the evidence shows this is not the standard used. The actual standard is a scintilla - a marginal difference from what is known. The consequence of such a low standard is that thousands of patents are granted for things that contribute no public benefit. Such trivial patents can impede genuinely inventive companies.

'The production of the knowledge of how to do in a somewhat different way what we have already learned to do in a satisfactory way would hardly be given highest priority in a rational allocation of resources.'

(Machlup 1958: 51)

\section{The reform process}

In 2009 the Australian government - through IP Australia — began a process to reform the standard patent system. This covered a range of issues but the focus of this article is the reform of the 'inventiveness standard'. IP Australia commented that there were 'a number of areas in which Australia's requirements for inventive step are set at a lower level than those of other jurisdictions' (IP Australia 2009a: 9). ${ }^{3}$ Particular concerns were 'allowable existing knowledge' and the 'test for inventiveness', as each can lead to the grant of patents for trivial inventions.

\footnotetext{
1 The Australian National University; hazel.moir@anu.edu.au. I would like to thank an anonymous referee and William Coleman for extremely helpful comments on the initial draft. Needless to say, the views presented in this paper are my own and do not represent the views of any other person or organisation.

2 Explanatory Memorandum, Intellectual Property Laws Amendment (Raising the Bar) Bill 2011: 42.

3 Lawson, reviewing a number of legal cases, also concluded that legal doctrines had driven Australia's inventive step to a very low level. He concludes that now 'obviousness will almost never be relevant in assessing patentability' (Lawson 2008: 44).
} 
The reform proposals were that:

- global common general knowledge replace Australian common general knowledge;

- statutory restrictions on allowable existing knowledge ('prior art') be removed; ${ }^{4}$ and

- one particularly low inventiveness test be replaced (see below).

The subsequent legislative amendments - the so-called Raising the Bar amendment bill - implemented the first two of these measures, but not the third. Removing the restrictions on allowable existing knowledge should reduce the volume of trivial patents granted in low-technology fields. But these changes will not affect trivial patenting in high-technology fields - there are no cases where restrictions to prior art have been used to uphold the validity of trivial patents in high-technology fields.

In 2009 IP Australia had proposed increasing the inventiveness threshold test from whether a skilled person 'would be led directly as a matter of course to try a particular approach with a reasonable expectation of success' (Lockwood $v$. Doric [2007] HCA 21, emphasis added) to 'obvious for the skilled person to try a suggested approach, alternative or method with a reasonable expectation of success' (IP Australia 2009a: 12-13, emphasis added). Such a change would have raised the inventive step from a scintilla to a small amount - a small step in the right direction. IP Australia later changed its position, advising that concerns about the low height of the inventive step would be addressed 'through restating the guidelines for inventive step in the Examiners' Manual and through more rigorous application of the inventive step tests during examination, rather than through changes to the law' (IP Australia 2009b: 12). On its face this reliance on the Examiners Manual seems dubious. Are Federal and High Court judges likely to accept that doctrines (policies) they have established are over-ridden by changes to a manual $?^{5}$

This article proceeds by reviewing why the inventiveness proxy is so central to economic balance in a patent system (Section 2). A consideration of how inventiveness is administered shows that the threshold for grant of a patent is set at a very low level. Section 3 presents empirical evidence on the quantum

\footnotetext{
4 Specifically, wording that allowed patent information to be excluded from allowable knowledge in lowtechnology fields (Commissioner of Patents v Emperor Sports [2006] FCAFC 26).

5 The changes are to the obvious to try section (2.5.3.3.5, modified August 2010) and to sections on mirror image chemicals (enantiomers) (section 2.5.3.4.1 and section 2.5.4.1.3, both modified in September 2012) (communication from IP Australia 13 February 2013). The Examiners' Manual is at http://www.ipaustralia. gov.au/pdfs/patentsmanual/WebHelp/Patent_Examiners_Manual.htm (accessed 23 September 2013). The amended 'obvious to try' section clarifies that such objections are relevant only if 'there is a reasonable expectation that the solution might well solve the problem'. Examiners are advised they must give reasons why they consider the solution obvious to try; for example, that the technology field is highly predictable. On its face, this does not appear to deal with the 'led directly as a matter of course' doctrine.
} 
of inventiveness required for a standard, demonstrating that this is indeed a scintilla not 'a significant advance in what is known'. With such a low threshold a very large proportion of granted patents will be for inventions with no spillover benefits. In the absence of systematic data on the cost of trivial patents, section 4 considers some limited evidence from legal decisions about the costs of trivial patents. Section 5 considers the options for reform, pointing particularly to the proposed Intellectual Property chapter in the Trans Pacific Partnership Agreement as a potential, but critical, impediment.

\section{Inventiveness}

Monopolies are generally anathema within the economics profession, and for good reason. But in patent policy the argument that the static efficiency losses from the monopoly grant will be offset by dynamic efficiency gains from new inventions is often accepted. This positive view of the patent intervention is based on a widespread belief that new technology provides significant spillover benefits. If such spillovers did not exist, the rationale for the patent intervention would disappear.

The patent eligibility criterion of the inventive step can be seen as a very rough proxy for the existence of spillover benefits. If an invention embodies significant new knowledge then spillover benefits are more likely. But if an invention contributes only trivial differences then there is no new knowledge, no spillovers and no rational basis for patent grant. Indeed grant of such patents will be welfare-reducing.

The legal and patent communities see the patent quid pro quo as the public disclosure of the invention. This is radically different to the economic perspective focusing on spillover benefits. Where the inventive step is high, the two perspectives can come into alignment with the public disclosure, providing a path through which the new knowledge can be disseminated. ${ }^{6}$ But if the inventive step is low, there is no useful knowledge content. In such cases disclosure simply adds noise to the system, hiding truly inventive patents.

Ideally patents would only be granted for inventions which would not otherwise take place and which provide spillover benefits. Both theory and data suggest that those inventions which are highly codified can be copied more quickly and cheaply (Mandeville 1996; Levin et al. 1987). In such cases, first-mover advantages could be insufficient to fully recoup expenses, particularly for highcost inventions. Unfortunately TRIPS (Article 27(1)) precludes limiting patents

6 Survey evidence suggests that very few industrial (or indeed academic) researchers look to patent databases for new knowledge (Mandeville, Lamberton and Bishop 1982; Oppenheim 2000; Macdonald 2003). 
to high-cost codified inventions. Firstly, TRIPS mandates no discrimination by technology field, so a limitation to inventions with highly codified technologies is not allowed. Secondly, TRIPS appears to mandate the current utility, novelty and inventiveness concepts as the sole screening devices for patent eligibility, implying that any other eligibility criterion, such as cost of R\&D, would contravene the treaty.

Neither TRIPS nor the Australia-US Free Trade Agreement (AUSFTA) preclude setting the inventiveness requirement at a level which maximises the likelihood of spillover benefits and minimises the likelihood of granting patents where there are no dynamic efficiency gains. Proposals to prevent such policy reform have been tabled during negotiations for the Trans Pacific Partnership Agreement (TPPA). ${ }^{7}$

Economic reviews have (reluctantly, as it is a blunt instrument) endorsed the patent system based on the assumption of a reasonable inventiveness standard (BIE 1994; IPCRC 2000). Given the clear evidence of a very low standard for grant of a patent, ${ }^{8}$ the assumption needs testing. It is, after all, critical to whether the dynamic efficiency gains are likely to offset the static efficiency losses.

Turning to how the inventiveness criterion is administered, it is surprising to an economist to discover that the first step is a series of rules which eliminate substantial existing knowledge from consideration. These rules determine the subset of existing knowledge ('prior art') that forms the baseline against which inventiveness is assessed. This is followed by rules determining how existing knowledge can be combined. Only after this is the question of the quantum of inventiveness addressed.

One might imagine this would be done by asking 'How much new knowledge or know-how is in this invention?' Not so. A reverse approach is taken - what the patent office and the courts ask is 'Is the invention obvious?' If it is not, a patent is granted. There are complex and detailed rules about determining obviousness. For example, the 'obviousness' judge must be a person skilled in the relevant art (PSA) and must not be imaginative (van Caenegem 2007: 85). ${ }^{9}$ In this context 'art' means technology field, and this has become very narrowly defined. For example, the Federal Court determined that well-known dynamic

7 http://keepthewebopen.com/assets/pdfs/TPP\%20IP\%20Chapter\%20Proposal.pdf Article 8(1), footnote 15.

8 The large literature on the low inventiveness standard is mostly based on US data (for example, Jaffe and Lerner 2004; Lunney 2004; Quillen Jr. 2006). Australia's inventiveness standard is considered to be lower (IP Australia 2009a: 6).

9 In the USA the Supreme Court has recently ruled that this skilled person has normal imagination (KSR $v$. Teleflex 127 S.Ct. 1727 (2007)). 
storage technology was inventive when used in a consumer-loyalty smart chip. ${ }^{10}$ Dynamic storage was well-known (obvious) to IT experts, but not to consumerloyalty experts. This seems to reward ignorance rather than inventiveness.

There is a large gulf between inventions embodying significant advances in knowledge and inventions which pass the 'Is it obvious?' test. A possible distribution of patent applications by inventiveness, where very many inventions have only a small degree of inventiveness, and only a small number are radically inventive, is shown in Figure 1. This allows a focus on the different outcomes achieved by asking 'Is it obvious?' compared to 'Is it sufficiently inventive?' Given the narrow and constrained approach to the patent test for obvious, many applications which pass this test will not be reach the 'significant advance' standard.

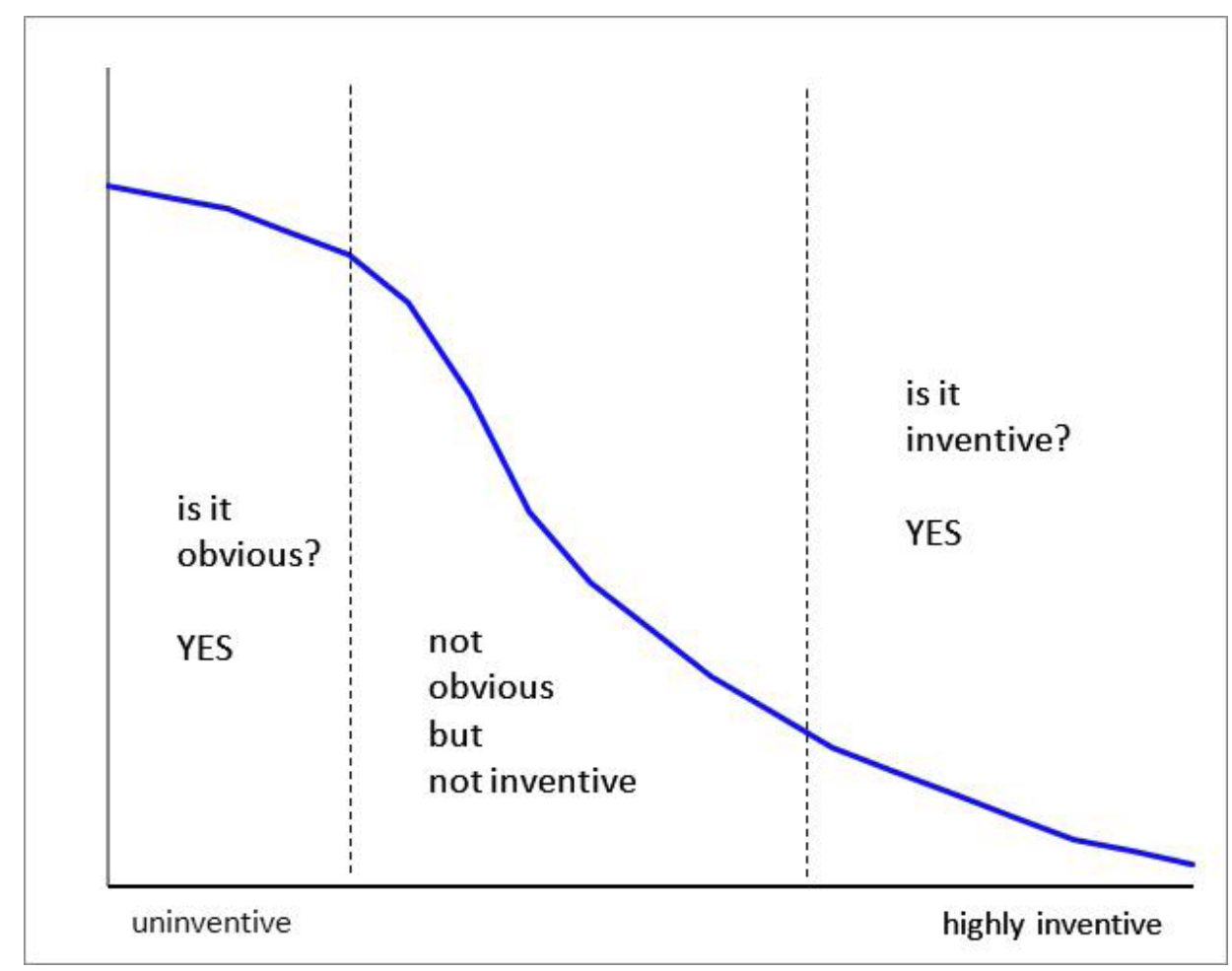

\section{Figure 1: Hypothetical inventiveness continuum and determining patentability}

Source: Author's representation.

10 Welcome Real-Time SA v. Catuity Inc, [2001] FCA 445 (17 May 2001). This issue, breadth of the technology field, is more fully considered by Bagley (2001), though with respect to US patent law. 
The two issues that set the inventiveness standard are the rules determining the 'prior art' and the rules determining inventiveness. Problems with the prior art rules should be fixed by the Raising the Bar amendments, though there is a substantial time lag before these take full effect ( 21 years from Royal Assent). ${ }^{11}$ But these rules have not been used to uphold trivial patent validity in hightechnology fields so will have no impact on, for example, the grant of the secondary (evergreening) pharmaceutical patents. This is where next step the rules determining inventiveness - are important.

\section{Inventiveness: Evidence from business method patents}

Inventiveness is qualitative and thus difficult to measure. While some studies use variables such as prior art citations, there is a lack of independent verification of these as good proxies for inventiveness (Gittelman 2008). Dahlin and Behrins (2005) have shown that the number of technology classes can provide a good measure of radical inventiveness, but the reverse does not work to identify obvious inventions. The one empirical study that does provide genuine insights into the quantum of inventiveness is of a set of 50 of the 'best' US software patents granted. ${ }^{12}$ This concluded that all were only incrementally inventive (Campbell-Kelly and Valduriez 2005).

My empirical study of business method patents was designed to provide an assessment of the inventiveness of granted Australian standard patents from an economic perspective. Instead of asking whether inventions were obvious, the research question was 'What new knowledge or know-how is contributed?' The dataset is a point-in-time universe of business method patents. All applications classified as business methods and filed in the years 2003 to 2006 were selected provided they had been sealed or accepted by 1 July 2007. The full specification was read for each of the 72 cases, and the claims were 'construed' to identify the essence of the invention. This was compared to knowledge at the time to identify what new knowledge was disclosed. ${ }^{13}$ None of the 72 cases disclosed any new knowledge though there were two possibly new ideas (which did not contribute

\footnotetext{
11 These changes apply only where examination was requested on or after 15 April 2013. The rationale for this lengthy implementation delay is unclear, given that all existing applications were grandfathered to the previous low standards. There was an avalanche of applications just before the change - the month to 14 April 2013 saw 6300 applications compared to around 2000 normally (http://blog.patentology.com. $\mathrm{au} / 2013 / 04 /$ raising-bar-raises-patent-filings.html).

12 'Best' was defined on the basis of forward citations (subsequent patents citing that patent), a variable which is associated with private value but has not been shown to be related to spillover benefits.

13 This step was completed by the December 2007. The relevant date for existing knowledge for each application (the 'priority date') ranges from 1998 to 2005.
} 
any new knowledge when implemented). ${ }^{14}$ In this article several cases from this study are discussed briefly to demonstrate the lack of new knowledge required for an Australian patent.

Many inventions take known elements and combine these in different ways. Such new combinations of well-known elements or processes ('combination' patents) raise substantial policy challenges. Early patent law did not face this difficulty as patents were available only for new inventions, not for improvements (Walterscheid 1995). Once patents for improvements were allowed (from 1776), courts had to face the challenge of dealing with combination patents. The synergy doctrine, still used in Europe, requires that to be patentable a combination of known elements must produce either a new and unexpected result or a result that is greater than the sum of its parts. That is, a combination of old elements can only be granted a patent if some new knowledge or knowhow is produced.

Unfortunately this doctrine was overturned in Australia in 1980 by the High Court. ${ }^{15}$ The US Court of Appeals for the Federal Circuit made a similar ruling a few years later (Harris 1986; Lunney 2004). Now, in both the USA and Australia, examiners may not reject applications which combine well-known elements or processes unless they can find written evidence that it is obvious to combine them. This can be hard to find. Examiners are thus forced to grant patents for such 'inventions' as teaching children about finance by having them work for their pocket money (more below). Although the 'suggestion' doctrine clearly leads to a very low inventiveness standard there have been no moves to reform it in the over three decades since its introduction. As the data in this section demonstrate, the consequence of this doctrine (policy), and other doctrines determining obviousness, is a standard that falls far short of a significant advance in what is known or used.

All 72 cases in my study involve at best only trivial variations from other known processes. Of these, 41 can be classified as 'combinations', of which 21 simply involve combining a known process with a computer. A further three combine known processes with modern electronic networks. Examples of computerisation cases include printing documents near the delivery point; automating financial analyses for pharmacies; an expert system to manage dialysis treatment; lodging patent applications; assessing organisational business risks; predicting when work elements become due; and valuing assets. The last of these (2005203023)

14 The original study provides a full discussion of the inventiveness and knowledge contribution of each case (https://digitalcollections.anu.edu.au/bitstream/1885/49313/4/02whole.pdf). An updated version looking at what rules lead to granting trivial patents (in Australia, Europe and the USA) is provided in Moir (2013).

15 Minnesota Mining and Manufacturing v Beiersdorf (1980) 144 CLR 253 at 117. 
simply computerises what every property valuer has done for decades. ${ }^{16}$ The examiner objected that the process was just common general knowledge, but the attorney argued that valuers often cut corners and failed to keep records. A patent was granted.

One of the network patents simply transfers the processes for ordering ID cards to the internet (2004201620). The process starts by verifying the client's computer's identity. The supplier then obtains appropriate data (over the internet) to populate the fields in the ID template. An image of the product is shown to the client for approval or amendment. That's it. Clearly this 'invention' would fail any ordinary meaning of the word 'inventive'.

Combination 'inventions' that were not simple computerisations include eight initially rejected by examiners. Claims were then amended and a patent granted. The correspondence between applicant and examiner shows how trivial are the distinguishing features which create what the patent system calls inventiveness.

- In the case of an on-line employment register (2005234625) the applicant successfully argued that the absence of features included in earlier systems created an inventive difference in this combination - a kind of 'less is more' argument.

- The inventive feature in a process for allocating patients to emergency facilities (2003248001) is a satellite communications gateway - a feature added to avoid rejection for lack of inventiveness. By adding one extra (known) feature the invention now became sufficiently inventive for a patent.

- In a process for combining date-stamped photos and written reports (2003246060) the report is generated on a server, rather at the site. This change in physical location was the key feature making this sufficiently inventive for a patent.

The dataset contained 18 cases where the 'inventions' were only trivial variations.

- An 'invention' to teach children about finance by working for their pocket money (2003203582) has multiple features - learning about credit by getting an advance is probably an 'invention' that every child has independently worked out. Less obvious elements are sickness insurance and buying shares or real estate. The combination of these many well-known elements in the environment of pocket money meant that the examiner could not find documented evidence of obviousness. If the synergy doctrine was still used

16 Application 2005203023. Numbers given for cases are application numbers and the specification can be found by entering this number into the AusPat database (http://pericles.ipaustralia.gov.au/ols/auspat/) then following the link for the B2 document. 
or if the inventiveness standard were a 'significant advance over what was known' this patent would not have been granted.

- A combined loan/investment 'invention' (2005265435) uses the loan both for the investment and to pay off part of the loan. It has five simple steps: receive loan parameters; determine rule-based payments; determine allocations for repayments between the loan and acquiring the investment; receive payments; and use payments based on allocation. A standard patent was immediately granted. There is nothing new about any element of this process - at the priority date (November 2004) a wide variety of geared investment products were on the market.

- An 'invention' predicting recurring events (2006200104, priority May 2005) is very similar to Microsoft's well-known Outlook product, available globally since 1997. The only difference is the option of the Julian calendar, a small additional feature. After examiner objections the claims were amended, moving some words from claim 2 into claim 1 . These words were a highly generalised specification of converting dates to numbers and back required for any computerised calendar system as computers can only work with binary data (ASCII). The patent was granted.

Of the remaining cases in the dataset, three involved analogous use of known processes, four simply link databases and three are just ideas, written at such a high degree of generality that no new knowledge is disclosed.

The analogous-use doctrine was developed to set a floor to the patent system by ensuring that patents were not granted for every trifling device. The English courts firmly established the principle that analogous uses (uses of a well-known thing for a different purpose for which its properties were well-suited) were not patentable as 'there would be no end to the interference with trade, and with the liberty of any mechanical contrivance being adapted, if every slight difference in the application of a well-known thing were held to constitute a patent ...' ${ }^{17}$

There are three cases in this dataset that appear to be simple uses of well-known processes in different contexts where their properties make them ideally suitable:

- Benchmarking was widely used during the micro-economic reform period of the late 1980s and early 1990s. ${ }^{18}$ The 'invention' here (2004200942, priority March 2003) is a classic application of benchmarking, using sustainability indicators for real estate projects and comparing their values with benchmarks. That's it.

17 Lord Chancellor in Hamilton (1865) at 1499. The principle was originally determined in 1838 when considering a patent claim for using a wheel on railway carriages (Brennan and Christie 1997: 239, citing Losh).

18 Australian government reports using this technique and dating from 1995 are at www.pc.gov.au. 
- Reward systems for consumer loyalty have a very long history. Loyalty 'stamps' were widely used in UK retailing in the 1960s. Modern versions include frequent-flyer reward schemes and Coles' Fly-Buys process. Patent 2003280529, priority November 2002, simply applies such an award system to tickets. A clear analogous use of a well-known process.

- The surprising thing about a patent for audit processes on the quantum of chemicals in foodstuffs (2004233489, priority November 2004) is that many similar patents had already been granted. As audit is a process designed to be used in a wide range of environments, none should have been granted. This one was in fact granted because it covered a slightly longer part of the supply chain. This marginal difference in the breadth of application was sufficient to achieve the alleged 'significant advance' standard for patent grant.

In case after case this research project demonstrates that the quantum of inventiveness required for grant of a standard patent in Australia is close to zero. None of the patents in the dataset contributed any new knowledge or knowhow. The minimum inventiveness standard for grant is clearly substantially below the claimed 'significant advance over what was known or used'.

How far can these results be extended to other technology fields? TRIPS mandates no discrimination by field of technology, so the patentability requirements of utility, novelty and inventiveness are applied in the same way whatever the technology field. The fact that none of the patents embodied any new knowledge (let alone a significant contribution) suggests that a very high proportion of granted patents generate no spillover benefits.

But some granted patents are inventive and deliver significant new knowledge. Work by Dahlin and Behrens (2005) suggests about 1 per cent are truly radical with up to 4 per cent being quite radical. Their dataset implies that in total about 20 per cent have some degree of real advance. This aligns well with informed (but never written) views from the patent community that about 5 per cent of patents are truly inventive, about another 10-15 per cent are quite inventive and the 80-85 per cent are 'rubbish'. ${ }^{19}$

In 2012, IP Australia granted 17724 patents. ${ }^{20}$ There are likely to be at least some genuine inventions among these - possibly as many as 3550. But some 14000 to 15000 may contribute few, if any, spillover benefits. Even if only 50 per cent of granted patents have no spillovers, this substantially increases the volume of patenting, imposing higher search costs on all innovating firms. It also allows for the substantial growth of a body of intermediaries who have a vested interest in larger volumes and hence lower standards. Allowing a very low standard also

19 Personal discussion with a (now retired) senior member of the Australian patent community, 7 October 2004. 20 Table 1, IP Australia, Australian Intellectual Property Report 2013 (http://www.ipaustralia.gov.au/aboutus/corporate/reports/?doc $=139839 \&$ view $=$ Detail). 
encourages a rent-seeking attitude and brings the law into disrepute. These all imply substantial resource misallocation - a resource misallocation that is a direct consequence of the patent system.

\section{What are the costs? Case law concerning trivial inventions}

Patents are a powerful exclusive right — the right to exclude others from operating in a particular technology space. As such, the only parties against whom patents can be enforced are innovating firms. ${ }^{21}$ Such costs can include changes to the firm's technology mix, additional R\&D to work round the patented space, licensing fees for technology which is very similar to what the firm invented itself, diversion of management time from running the business, fines and penalties as well as not insubstantial legal costs. Although the major policy concern is with the social costs of patent systems, most of the limited available data are on private costs (Moir 2009).

When it comes to the key area of concern - the possibly chilling effect on the innovation activities of other firms through exclusion or high license fees - few data are available. Some argue, without any empirical evidence, that few patents are used, so trivial patents are unlikely to inflict any economic damage (Lemley 2001; Blonder 2005). Other commentators (for example, Gans, Williams and Briggs 2004) consider that in most circumstances the effective monopoly power conferred by a patent is weak, and such costs will therefore be low to non-existent. If this is so, it is hard to see how patents create an incentive for $\mathrm{R} \& \mathrm{D}$ investment.

The policy interest is in how often innovating firms are held up by trivial patents owned by others and how significant such hold-up is. The National Innovation Survey does not collect data on whether firms have incurred costs due to patents held by other parties. Nor does the patent office collect any data on the use of the over 17000 patent monopolies it currently hands out each year. ${ }^{22}$ In any other policy area such lack of outcome data would be severely criticised. But patents are off-budget so are not subject to normal audit and evaluation processes. Reviewing the historical evidence, Cohen finds that technological hold-ups can and do occur (Cohen 2005).

In the absence of systemic data on this important issue, one can consider the evidence from court cases. Even here, however, data are limited as costs and

21 Bessen and Meurer (2007). Individuals and micro-firms are usually not worth pursuing.

22 Despite IPAC's recommendation that such data be collected at the time patents are renewed (IPAC 1984).

No patent office collects data on patent use. 
damages are determined separately from substantive outcomes. As a result, databases on litigation outcomes rarely include cost data and where they do the data are limited to legal costs. ${ }^{23}$ But the greatest policy concern is not legal costs but the range of other costs an innovating firm can experience if it is held up or diverted because of trivial patents.

Australian judgements where trivial patents are upheld and found to be infringed each point to firms who have been fined and forced to work around their own. Doric fought for seven years against a patent owned by Lockwood. But the High Court found that it was not obvious to take an element from a storeroom lock to fix a problem with a rim-mounted lock. ${ }^{24}$ Doric had to pay costs, damages and stop using technology it invented. When the Federal Court upheld the validity of a dynamic storage card for a consumer loyalty use - even though all parties agreed dynamic storage was well-known in the IT area - Catuity had to stop using its own similar technology. ${ }^{25}$ In every case where a court upholds a trivial patent as valid there is a firm which pays the price for these low standards.

When these trivial patents involve pharmaceuticals, some elements of their cost can be estimated. Clear policies for price falls for drugs listed on the Pharmaceutical Benefits Scheme (PBS) after generic entry allow estimation of the costs to taxpayers of delayed generic entry. Submissions to the recent pharmaceutical patents review provided data on a number of such cases. ${ }^{26}$ The cost to taxpayers is different to the cost to generic firms of delayed entry, but it does show the magnitudes that can be involved:

- Efexor (venlafaxine) came off patent in late 2008. In the market it had effectively been replaced by the extended release version Efexor-XR. Generic entry of Efexor-XR was delayed for $2 \frac{1}{2}$ years by a patent dispute. With this high volume drug the estimated cost to the taxpayer from the delayed price fall is A $\$ 209$ million.

- During this time Pfizer heavily marketed a closely similar drug desvenlafaxine - which has the identical therapeutic effect as venlafaxine. This achieved a 37 per cent market share for the replacement drug at an estimated annual cost to the taxpayer of $\mathrm{A} \$ 6.7$ to $\mathrm{A} \$ 7.6$ million a year. As venlafaxine is metabolised to desvenlafaxine in the human body, it is surprising that a patent was granted for such a small variation.

\footnotetext{
23 For example, Dent and Weatherall (2006) have no cost data. Helmers and McDonagh (2012) include limited data on private legal costs. A very small survey undertaken for the UK Strategy Advisory Board for Intellectual Property Policy (SABIP) asked firms involved in patent disputes about legal costs and management time taken in disputes. The survey was supplemented by in-depth interviews which show that the management time issue had a major negative effect on many businesses (Greenhalgh et al. 2010).

24 Lockwood v. Doric [2007] HCA 21.

25 Welcome Real-Time SA v. Catuity Inc, [2001] FCA 445 (17 May 2001).

26 The website for the pharmaceutical patents review and the submissions to this has been taken down. Copies of submissions, the issues paper and the draft report can be obtained on request to the author.
} 
- It is well known that one isomer of a racemic drug will be more effective than the other, and often more effective than the racemic mixture. The Patent Examiner's Manual was revised in September 2012 to state that patents on isomers would rarely be granted. Before this, Sanofi was granted a patent over the racemic mixture of clopidogrel then a further patent over its isomer (marketed as Plavix). A term extension was granted on the isomer patent. The isomer patent was eventually challenged and revoked, but it kept generic versions off the market for some $2 \frac{1}{2}$ years at an estimated cost to the taxpayer of $\mathrm{A} \$ 60$ million during the injunction period.

- Clopidogrel is an anti-platelet agent that inhibits blood clotting. Sanofi also obtained a patent on the combination of clopidogrel and aspirin. Like clopidogrel, aspirin is used as a blood thinning agent - and has been known since 1899. Although both drugs were known, and were known for their use for the same purpose, the patent for the combination delayed generic entry. Eventually the combination patent was challenged. Sanofi resisted the challenge until the directions hearing on 29 May 2012 when it chose not to defend the patent - a clear sign of a very 'weak' patent. But this patent gave Sanofi $2 \frac{1}{2}$ years of higher prices at an estimated cost to taxpayers of $\mathrm{A} \$ 11$ million. ${ }^{27}$

\section{Patent policy reform: Opportunities and threats}

In 1984 the Fraser government asked IPAC to review the economic impact of the patent system. The review committee commissioned a range of empirical work and held a number of excellent seminars (Mandeville et al. 1982b, 1982a). But the one economist on the committee lodged a dissenting report claiming that there was little economic analysis in the actual report (IPAC 1984: 79-80). Instead, he said, the proposals pandered to sectional interests and missed an important opportunity for reform. Similarly the review of the patent system under the Competition Principles Agreement (the Ergas Report) simply assumed that patents were necessary and that the inventive step was at least reasonably high. Another opportunity for effective reform was missed. The draft report of the 2012-13 Pharmaceutical Patents Review accepted the proposition that a change had been made to inventiveness standards for pharmaceuticals despite the lack of any evidence to support this (Australian Government 2013: 121-4).

As noted in the introduction, IP Australia put forward proposals for a marginal increase in the inventiveness test in 2009, but then backed away this. The reasons given were that a number of submissions considered this 
unnecessary (IP Australia 2009b: 12). None of the submissions to this reform process were ever made public, so it is unclear which parties argued to maintain the current very low standards.

It is clear, however, that a low standard means many more applications and thus directly affects the income for intermediaries. Patent Attorneys were established as a protected profession in the 1952 Patent Act - the patent equivalent of tariff consultants - and there are now 860. ${ }^{28}$ Patent applicants are officially advised to 'seek professional advice from a patent attorney'.$^{29}$ The cost per application is $\$ 8000$ or more (IP Australia 2013: 32). Another major beneficiary of low standards is the brand pharmaceutical industry which uses these low standards to obtain follow-on patents to extend their period of market exclusivity (Kapczynski et al. 2012). Burdon and Sloper (2003: 238) advise that while very uninventive patents may incur litigation, the returns to the patent owner will easily outweigh litigation costs, even when the patent is found invalid.

The imperviousness of the patent system to genuine reform is explainable by focusing on the interest groups involved and regulatory capture theory. The risks faced by innovating firms are widely distributed and there are no systems in place for collecting data on these risks and their cost. ${ }^{30}$ Associated with this lack of any direct data on costs and benefits, there have been no economic evaluations of Australia's patent system. ${ }^{31}$ The Productivity Commission, for example, has never been tasked with assessing whether the patent system contributes a net welfare benefit to Australia.

A further reason for the lack of any reform effort is that the patent system is offbudget. This was one reason why it appealed to notoriously poverty-stricken European monarchs. Now it reduces the imperative for reform. Combined with substantial lobbying resources - which successfully promote unsubstantiated slogans such as 'patents are essential for innovation' ${ }^{32}$ — the lack of action is readily explained.

It becomes, however, a very risky strategy now that large global companies have successfully persuaded governments to insert these restraints on competition

\footnotetext{
28 These data were provided by IP Australia in response to my enquiry. Data on the number of Patent Attorneys registered each year do not appear to be publicly available - the regulatory board publishes no summary data or annual reports (http://www.psb.gov.au).

29 http://www.ipaustralia.gov.au/get-the-right-ip/patents/patent-application-process/ as at 21 April 2013.

30 There is evidence that in the USA data collection and analysis has been successfully opposed by patent attorneys and major patenting firms (Kahin 2003). The Federal Trade Commission recommendation (FTC 2003) most prominently rejected by the Intellectual Property Owners Association (dominated by patent lawyers from large firms) was recommendation 10 'expand consideration of economic learning and competition policy concerns in patent law decisionmaking' (Bessen and Meurer 2008: 293-4).

31 Indeed, I have not been able to locate a sound economic evaluation of any patent system in any country. 32 One of the global experts on the relationship between patents and innovation has concluded that the patent system 'has been neither necessary nor sufficient for technical and/or economic progress at country and company level historically' (Granstrand 1999: 44).
} 
into the global trading system. If a country wants to participate in GATT it must provide patents, trademarks, copyright and so on, as mandated in TRIPS. The US government is pursuing TRIPS-Plus standards in bilateral and regional trade agreements, and the AUSFTA is an example. The Productivity Commission has warned strongly against including such non-trade issues in trade agreements (Productivity Commission 2010).

A leaked draft of the Intellectual Property chapter of the Trans Pacific Partnership Agreement provides detailed prescription on how patents, trademarks and copyright should be administered, including determining inventiveness by the 'Is it obvious?' approach. While this draft has been withdrawn and replaced, the secrecy surrounding the discussions continues to raise concerns about inappropriate intellectual property privileges being traded for small gains in agricultural exports. This would be a poor bargain as it is domestic market reforms, not enhanced expert access, which lead to the major gains from global trade (Armstrong 2012: 1641). Further, it is information-intensive industries which are expected to show most future growth. To tie the hands of current and future governments with respect to reform in this important area of innovation policy would be an extremely expensive outcome.

New material about the cost of the low-inventiveness standard was placed on the table during the previous government's pharmaceutical patent review panel. This showed that the cost to taxpayers of secondary pharmaceutical patents can be substantial. In the current budgetary climate, proper reform of the patent inventiveness standard would flow directly to substantially reduced outlays through the PBS as exclusive marketing periods would no longer be extended through evergreening patents. Perhaps this can be an incentive to undertake genuine reform of the patent system?

While Australia is not alone in having a very low inventive step for grant of a patent monopoly, the fact that other countries have dysfunctional patent systems is no reason for Australia to follow suit. When it came to dismantling tariff barriers Australia had no hesitation in identifying that it was in Australia's economic interests to do this, whether others did so or not. We also showed leadership on reforming agricultural subsidies. Using the principles set forth in the Competition Principles Agreement, we could now show leadership in reforming patent systems to remove their worst excesses. This could be of benefit to many of our trade partners as well as to ourselves. 


\section{References}

Armstrong, S. 2012, 'Australian Trade Policy Strategy Contradictions', The World Economy: 1633-44.

Australian Government 2013, 'Pharmaceutical Patents Review: Draft Report', Canberra; available at: http:/www.ipaustralia.gov.au/about-us/iplegislation-changes/review-pharmaceutical-patents/ (viewed 23 September 2013).

Bagley, M. 2001, 'Internet business model patents: obvious by analogy', Michigan Telecommunications Technology Law Review 7: 253-88.

Bessen, J. E. and Meurer, M. J. 2008, Patent Failure: How Judges, Bureaucrats, and Lawyers Put Innovators at Risk, Princeton and Oxford: Princeton University Press.

BIE 1994, 'The Economics of Patents', Canberra.

Boldrin, M. and Levine, D. K. 2008, Against Intellectual Monopoly, Cambridge: Cambridge University Press.

Burdon, M. and Sloper, K. 2003, 'The Art of Using Secondary Patents to Improve Protection', Journal of Medical Marketing 3(3): 226-38.

Campbell-Kelly, M. and Valduriez, P. A. 2005, A technical critique of fifty software patents', Marquette Intellectual Property Law Review 9(2): 249305.

Cohen, W. M. 2005, 'Patents and appropriation: concerns and evidence', Journal of Technology Transfer 30(1-2): 57-71.

Dahlin, K. B. and Behrens, D. M. 2005, 'When is an invention really radical? Defining and measuring technological radicalness', Research Policy 34(5): 717-37.

FTC 2003, To Promote Innovation: The Proper Balance of Competition and Patent Law and Policy, Washington, D.C.: Federal Trade Commission (US).

Gans, J. S., Williams, P. L. and Briggs, D. 2004, 'Intellectual property rights: a grant of monopoly or an aid to competition?' The Australian Economic Review 37(4): 436-45.

Gittelman, M. 2008, 'A note on the value of patents as indicators of innovation: implications for management research', Academy of Management Perspectives 22(3): $21-7$. 
Granstrand, O. 1999, The Economics and Management of Intellectual Property - Towards Intellectual Capitalism, Cheltenham, UK and Northampton, MA, US: Edward Elgar.

Greenhalgh, C., Philips, J., Pitkethly, R., Rogers, M. and Tomalin, J. 2010, 'Intellectual Property Enforcement in Smaller UK Firms', Report for the Strategy Advisory Board for Intellectual Property Policy (SABIP).

Harris, R. W. 1986, 'Prospects for Supreme Court review of the Federal Circuit standards for obviousness of inventions combining old elements', Journal of the Patent and Trademark Office Society 68(2): 66-82.

Helmers, C. and McDonagh, L. 2012, 'Patent Litigation in the UK', London.

Hemphill, C. S. and Sampat, B. N. 2012, 'Evergreening, Patent Challenges, and Effective Market Life in Pharmaceuticals', Journal of Health Economics 31: 327-39.

IP Australia 2009a, 'Getting the Balance Right: Toward a Stronger and More Efficient IP Rights System', Canberra: IP Australia.

2009b, 'Toward a Stronger and More Efficient IP Rights System: Proposed Reforms', Canberra: IP Australia.

2013, 'Australian Intellectual Property Report 2013', Canberra.

IPAC 1984, Patents, Innovation and Competition in Australia, Canberra: Industrial Property Advisory Committee; available at: http://www.acip.gov. au/reviews_other.html.

IPCRC 2000, 'Review of Intellectual Property Legislation Under the Competition Principles Agreement: Final Report', Canberra: Attorney-General's Department (Intellectual Property and Competition Review Committee).

Jaffe, A. B.and Lerner, J. 2004. Innovation and its Discontents: How Our Broken Patents System is Endangering Innovation and Progress, and What to Do About It, Princeton: Princeton University Press.

Kahin, B. 2003, 'Information process patents in the US and Europe: policy avoidance and policy divergence', First Monday 8(3).

Levin, R. C., Klevorick, A. K., Nelson, R. R. and Winter, S. G. 1987, 'Appropriating the returns from industrial research and development', Brookings Papers on Economic Activity, Special Issue on Microeconomics 1987(3): 783-831.

Lunney Jr., G. S., 2004, 'Patent law, the Federal Circuit, and the Supreme Court: a quiet revolution', Supreme Court Economic Review 11: 1-79. 
Macdonald, S. 2003, 'Bearing the burden: small firms and the patent system', The Journal of Information, Law and Technology (JILT) 2003(1) at: http:// www2.warwick.ac.uk/fac/soc/law/elj/jilt/2003_1/macdonald/.

Machlup, F. 1958, AAn Economic Review of the Patent System (Study No.15 of the U.S. Senate Subcommittee on Patents, Trademarks and Copyrights)', Washington, D.C.: US Government Printing Office.

Mandeville, T. D. 1996, Understanding Novelty: Information, Technological Change, and the Patent System, Norwood, N.J.: Ablex.

Mandeville, T. D., Lamberton, D. M. and Bishop, E. J. 1982, Supporting Papers for the Economic Effects of the Australian Patent System, Canberra: Australian Government Publishing Service.

Moir, H. V. J. 2009, 'What are the costs and benefits of patent systems?' in Intellectual Property Policy Reform: 29-54, W. Van Caenegem and C. Arup (eds), Cheltenham, UK and Northampton, MA, US: Edward Elgar.

Oppenhiem, C. 2000, 'Patent information usage in British small and medium sized enterprises'.

Productivity Commission 2010, 'Bilateral and Regional Trade Agreements', Canberra: Productivity Commission Research Report.

Quillen Jr., C. D. 2006, 'Innovation and the U.S. patent system', Virginia Law and Business Review 1: 210-25.

Steensma, D. P. and Loprinzi, C. L. 2006, 'Epoetin Alfa and Darbepoetin Alfa Go Head to Head', Journal of Clinical Oncology 25(15): 2233-6.

Walterscheid, E. C. 1995, 'The Early Evolution of the United States Patent Law: Antecedents (Part 3 continued)', Journal of the Patent and Trademark Office Society 77(11):847-57. 